\title{
Evaluation of Malaysian English Language Teaching Textbooks
}

\author{
Jayakaran Mukundan (Corresponding author) \\ Department of Language and Humanities Education, Faculty of Educational Studies \\ Universiti Putra Malaysia, 43400 UPM Serdang, Selangor, Malaysia \\ Tel: 60-3-8946-6000Ｅ-mail: jayakaranmukundan@yahoo.com \\ Seyed Ali Rezvani Kalajahi \\ Department of Language and Humanities Education, Faculty of Educational Studies \\ Universiti Putra Malaysia, 43400 UPM Serdang, Selangor, Malaysia \\ Tel:60-122566070_ E-mail: ali.rezvani85@gmail.com
}

Received: 17-05- 2013

Accepted: 27-06- 2013

Published: 01-07- 2013

doi:10.7575/aiac.ijels.v.1n.1p.38

URL: http://dx.doi.org/10.7575/aiac.ijels.v.1n.1p.38

\begin{abstract}
Research in materials evaluation has been an important focus in ELT since the 1980s. The objective of the present study is to evaluate the general attributes of the textbooks and to evaluate the learning-teaching content. In this study, 944 male and female English teachers (Year 1 to Year 6 \& Form 1 to Form 5) evaluated the English books using a valid and reliable checklist. In terms of general attributes and learning-teaching content of the textbooks, the results showed that Year 1 to Year 6 teachers reported that the current textbooks are 'highly useful' to the students, whereas Form 1 to Form 5 teachers contended that the school books are only 'moderately useful'. The findings of this study can be useful for curricula designers and Ministry of Education as a reference for improving or modifying the textbooks.
\end{abstract}

Keywords: textbook evaluation, ELT-TEC, checklist, Malaysian teachers

\section{Introduction}

Materials evaluation is quite a new phenomenon in the field of language teaching. Tomlinson (2001, p.66) defines materials as "anything which can be used to facilitate the learning of a language." ELT materials, in particular, (textbooks) play a very significant role in many language classrooms but in recent years there has been a lot of discussion throughout the ELT profession on the actual role of materials in teaching English as a Second/Foreign Language (Litz, 2005). The choice of language teaching materials can determine the quality of learning-teaching. Hence, particular and serious attention must be paid to evaluate such materials based on valid and reliable instruments (Mukundan, Nimehchisalem \&Hajimohammadi, 2011).

\subsection{Statement of the problem}

In an attempt to examine the effectiveness of textbooks used in the classroom, TESL researchers in Malaysia conducted studies on the evaluation of textbooks currently used in secondary schools (Ghazali, 2008; Mukundan, 2003, 2007). These studies were conducted to examine the suitability of the Malaysian school English language textbooks, and whether or not learners would get the desirable benefit from the content of these books in order to achieve the educational objectives. They all reported that the textbooks that they evaluated needed some improvements and they recommended evaluating the textbooks using different instruments and larger sample sizes before making sure their findings can be generalized.

So, even though the vetting had been done by the Textbook Division of the Ministry of Education (MOE), it is necessary for teachers to evaluate the textbooks because in their teaching-learning contexts, a particular textbook may not be able to contribute positively to students' development in the acquisition of the English Language. Indeed, sometimes, a textbook may lead to learners' failure in acquiring the language and in worst cases, it may contain serious pedagogical flaws and other shortcomings (Litz, 2005; Tomlinson, 2008)

With regard to this problem of failure or success of a textbook, it is useful to conduct ELT textbook evaluation so as to ensure that ELT textbooks can effectively facilitate the achievement of teaching objectives (Mukundan, 2007). Often it is the only resource for both teachers and learners in some learning-teaching contexts. It is, therefore, the researchers' aims to evaluate the English textbooks so as to ensure that they are suitable for the learners and capable of helping teachers to realize the pedagogical goals of the new curriculum.

\subsection{Research questions}

1. How did the teachers evaluate the general attributes of the textbooks?

2. How did the teachers evaluate the learning-teaching content? 
1.3 Significance of the Study

The findings of the study are expected to offer some suggestions to help the English language teachers with the use of the textbook. The evaluation results can help to enhance the effectiveness of the use of the textbook by helping teachers to understand what areas of the textbook need adaptation, or to what extent use of other possible teaching materials is necessary.

\section{Literature Review}

It seems that there can be very little teaching done without the textbook. Teachers seem to believe that it saves them time and financial resources as DIY (Do-IT-Yourself, or teacher-developed materials) are costly and require greater use of teacher-time. As Hutchinson and Torres (1994 cited in Litz, 2005) state:

The textbook is an almost universal element of [English language] teaching. Millions of copies are sold every year, and numerous aid projects have been set up to produce them in [various] countries...No teachinglearning situation, it seems, is complete until it has its relevant textbook. (p. 315)

Yet, various attitudes exist toward textbooks. For instance, Tomlinson (2001) shares the attitudes into two groups: proponents and opponents. The former group contends that textbooks are the most convenient form of presenting materials because they offer consistency, systematicity, cohesion, continuation, and progression, whereas the latter contend that textbooks are inevitably superficial and reductionist in their coverage and are not able to satisfy the diverse and broad needs of all their users. Therefore, it is implied that the first group views textbooks as useful for general purposes while the second group considers the shortcomings of textbooks as context-related. Despite entire disagreements, it is widely agreed that textbooks are of great value in the process of teaching and learning (Cunningsworth, 1995; Haycroft, 1998; O’Neil, 1982; Sheldon, 1988).

Sheldon (1988) states that there are numerous reasons for the evaluation of textbooks. Among these reasons, he proposes that the selection of an English language teaching textbook often demonstrates an important administrative and educational decision which involves considerable amount of professional, financial, or even political investment. In addition, Ellis (1997) proposes that material evaluation could be conducted at three stages:

1) 'predictive' or 'pre-use' evaluation that is designed to examine the future or potential performance of a textbook;

2) 'in-use' evaluation designed to examine material that is currently being used; and

3) 'retrospective' or 'post-use' (reflective) evaluation of a textbook that is concerned with the evaluation of textbooks after they have been used in a specific institution or situation.

This study is an "in-use" evaluation of a number of textbooks using an established checklist.

\subsection{The Role of Textbooks in the EFL/ESL Classroom}

A textbook is referred to as a published book specially designed to aid language learners to improve their linguistic and communicative abilities (Sheldon, 1987). In addition to being learning tools, textbooks are also used as supporting teaching materials (O'Neil, 1982, \& Ur, 1996). The student's book usually comes with other materials such as a workbook, a teacher's book or even additional multimodal texts for reference as a textbook package (Masuhara\& Tomlinson, 2008). They are "designed to give cohesion to the language teaching and learning process by providing direction support and specific language-based activities aimed at offering classroom practice for students" (Mares, 2003) and promote effective and swift learning of the language (Cunningsworth, 1995).

\subsection{The Need for Textbook Evaluation}

The ever increasing number of textbooks on the market makes formulating the right choice in textbooks difficult (Cunningsworth, 1995, Green 1926). Textbook selection can have a massive impact on the teaching and learning process (Cunningsworth, 1995; Harmer, 1991; McGrath, 2002). In that sense, the quality of a textbook might be so important that it can determine the success or failure of an ELT course (Green 1926, Mukundan 2007). However, textbooks are often purchased without careful analyses (Green, 1926, McGrath 2002). Frequently, textbook selection is not based on its intrinsic pedagogical value, but of the perceived prestige of the author and or the publisher (Green 1926, McGrath 2002), or skillful marketing by the publishers (McGrath, 2002).

A number of studies have suggested that most current global, ELT textbooks are developed for commercial purposes and are not based on principles of language acquisition and development recommended by scholars and educators (Tomlinson, 2003, $2008 \&$ 2010). Financial success has become the primary goal of textbook publishing (Sheldon 1988, Litz 2005, Tomlinson, 2003).

"Textbooks, like any other book that publishers print, are pieces of merchandise; the ultimate objective of their production is [for] commercial success" (Dendrinosm 1992:35). Instead of contributing positively to student's development in the acquisition of the English language, many textbooks are in fact leading to learner's failure in acquiring the language and in the worst case, contain serious pedagogical flaws and practical shortcomings (Litz 2005, Tomlinson 2008:3).

Tomlinson (2008) mentions two causes for learning failure. The first cause of failure is possibly motivated by the need of commercial success, which is, publishers would have to produce books based on the public demand. Textbook writing as a result is moulded according to the liking of teachers, parents and administrators with a heavy focus on the teaching of linguistic items instead of creating opportunities for students to acquire the language through usage (Tomlinson, 2008). Also, teachers tend to choose textbooks that are designed to allow for minimal preparation for their 
classes (Dendrinos, 1992,Tomlinson 2008,\& 2010). The second cause of failure is that instead of focusing on how learners could actually benefit from using the textbook, textbook writers rely on their intuition and produce materials what they think would work best for their intended users (Tomlinson, 2008:7). They are biased towards perceived rather than actual needs of learners (Tomlinson, 2003). Though the textbooks written by professional writers are usually of good quality in terms of organization, packaging and design, they tend to be lacking in qualities of being creative and imaginative(Tomlinson, 2003). Litz (2005) also suggested that some more recent scholars in the area of ELT materials development expressed concerns for the cultural content of textbooks which are "inherently socially and culturally/ biased" and help to preserve a form of "gendered" English (Banegas, 2011, Litz, 2005: 6).

In view of the above, it is, therefore, very important for us to conduct ESL/EFL textbook evaluation so as to ensure ELT textbooks can effectively facilitate the attainment of our teaching objectives, and at the same time, be economically viable to teachers and students. Wrong choice of textbooks would be likely to negatively affect both teaching and learning. Financial resources would also be wasted (Mukundan, 2007; Sheldon, 1988).

\subsection{Past Research on ESL Textbooks Evaluation Studies}

Mukundan (2003) highlighted that in order to avoid problems in evaluating a textbook, the evaluation has to be systematic and effective. The point is, of course, that a global list of criteria can never really apply in most local environments, without considerable modification.

There are a lot of studies around the world that evaluated the textbooks used in the school systems. These studies consider textbook from different points of view with different instruments.

Chao (2009) retrospectively evaluated the English textbook used in a chosen local college in Taiwan based on Intercultural Competence Model (ICC). This textbook was written by a local publisher. As the findings showed, the content in the textbook did not seem to help English learners develop intercultural abilities. The results showed also that although the textbook was colourfully filled with photos and pictures, there was no explanation of its meaning, function, location, and source of each photo. As for teacher's manual, the design of this teacher's manual reflected the traditional need of Taiwanese English teachers and learners in language classrooms.

Nemati (2009) evaluated English Pre-University textbook of Karnataka State in India in terms of the merits and demerits of the textbooks, and in specific vocabulary teaching strategies. The teachers in government and nongovernment schools seem to be fully satisfied with the textbook. According to the results, the teachers believed that the textbook has the main criteria that are fundamental and necessary for any textbook such as the presentation of the four main language skills. The evaluated textbook was acceptable in terms of the topics that make the students familiar with different aspects of their culture as well as with customs and culture of English countries and other countries. The book was clearly organized and graded from easy to difficult. The book taught principles of paragraph writing. It also did not neglect speaking and includes dialogues and role play or communicative activities. As for the vocabulary analysis, (Nemati, 2009) suggests that it is better to change the sequence of presenting the text so the texts with more frequent vocabulary and as a result easier ones come first and texts with rare and much more difficult vocabularies appear towards the end of the book.

Kırkgöz (2009) evaluated three English textbooks which were used in grade 4 in the primary schools in Turkey. A great balance was observed between the responses of the teachers and students. The findings from the questionnaire and the interview were also consistent. The participants appreciated the textbooks in their layout with the attractive design and well-produced illustrations. They had interesting and well-presented vocabulary, clear and understandable instructions, containing authenticity in examples, activities, topic and subject content. They promoted a balanced development of the four language skills (reading, listening, writing and speaking).

Aroo (2012) evaluated the suitability of the newly introduced textbook namely, English Year 2. Findings revealed that, overall, the teachers considered the textbook highly suitable for the learners. In Aroo's study, two teachers evaluated the textbook. On average, the first teacher rated the textbook 2.90 (upon 4.00) that was slightly lower than the second teacher's rating $(M=3.10)$. However, in reference to the score interpretation guide provided by Mukundan and Nimehchisalem (2011), both scores fall under the same level of 'high suitability'. In Aroo's study, with respect to the overall suitability of the textbook and its ability to fulfil the needs of the learners, both teachers were dissatisfied with the speaking, reading and writing activities although they had been designed to fit the objectives of the syllabus. Writing activities and exercises were too limited in the textbook. The results also indicated that new words were not repeated in the subsequent parts of the book. As for grammar, it was not explicitly presented in this textbook because of the low age of the learners. Grammar is introduced from Year Three onwards. In terms of components like content, syllabus, pronunciation, layout, durability, and printing quality the book would fulfil the requirements of a good textbook.

Mukundan and Roslim(2009) present a corpus-based investigation on English preposition presented in three English language textbooks used by lower secondary schools in Malaysia. The findings showed that there is a difference between the words in the textbook corpus and the BNC (British National Corpus) in terms of frequency order of certain prepositions. The findings can guide teachers in deciding how best to supplement the text with activities that will give learners exposure to target grammar item that is not sufficiently presented in the textbook.

Mukundan, Leong and Nimehchisalem (2011) analysed the distribution patterns of the articles in the five Malaysia Secondary English language textbooks. They analysed the content of the articles and found out there is lack of variety in exercises on articles. 


\section{Method}

The objectives of the present study were to evaluate the general attributes of the textbooks and to evaluate the learningteaching content. To meet these objectives quantitative method, descriptive in nature, was used.

\subsection{The evaluators}

A total number of 944 evaluators took part in this study. The evaluators of this study were male $(18 \%)$ and female (92\%) English teachers of Year 1 to Year 6 and Form 1 to Form 5 from urban and rural schools in Melaka State, Malaysia. Table 1 provides further information on the specific number of the evaluators from each grade who participated in this study.

Table 1. Number of evaluators from each grade

\begin{tabular}{cccc}
\hline Grades & Number & Grades & Number \\
\hline Year 1 & 115 & Form 1 & 57 \\
Year 2 & 112 & Form 2 & 55 \\
Year 3 & 108 & Form 3 & 54 \\
Year 4 & 112 & Form 4 & 56 \\
Year 5 & 105 & Form 5 & 56 \\
Year 6 & 114 & & \\
Total & 666 & Total & 278 \\
\hline
\end{tabular}

\subsection{Data Collection Method}

\subsubsection{The checklist}

In this research, a checklist proposed by Mukundan and Nimchisalem (2011) (Appendix 1) was adopted by the researchers. The checklist is called the English Language Teaching Textbook Evaluation Checklist (ELT-TEC), a userfriendly instrument that has been validated and tested for its reliability. It was developed by a review of the literature (Mukundan \& Ahour, 2010; Mukundan, Hajimohammadi, \&Nimehchisalem , 2011) and was refined through qualitative (Mukundan, Nimehchisalem, \& Hajimohammadi, 2011; Nimehchisalem \& Mukundan, In Press, a) and quantitative (Mukundan \& Nimchisalem, 2011) methods.

It contains two main categories: i) The textbook general attributes ii) Textbook learning Content

There are five major components under general attributes which are (a) Syllabus and curriculum, (b) Methodology, (c) Suitability to learners, (d) Physical and Utilitarian Attributes, (e) Efficient outlay of supplementary materials.

There are major components under learning-teaching contents which are (a) General content, (b) Listening, (c) Speaking, (d) Reading, (e) Writing, (f) Vocabulary, (g) Grammar, (h) Pronunciation, and (i) Exercise.

The rating system is based on a 5 -point scale; 0 = NEVER TRUE; 1 = RARELY TRUE; 2 = SOMETIMES TRUE; $3=$ OFTEN TRUE; 4 = ALWAYS TRUE; in case the item is not applicable, the evaluator may use the option as NA= NOT APPLICABLE. In order to interpret the date easily, there is a table that provides information and guide to interpret the findings.

This checklist is user friendly, cost effective, systematic, easy to understand, and ensures that all elements that are deemed to be important in textbook evaluation.

\subsubsection{The Validity of the Instrument}

The English language Teaching Textbook Evaluation Checklist (ELT-TEC) has been tested for its validity by Nimehchisalem and Mukundan (In Press, b). In their study, a group of evaluators ( $n=82)$ who used the checklist to assess a textbook, indicated high to very high (72-95\%) levels of satisfaction with the ELT-TEC. The instrument has also proved to be economical. On average, it took the evaluators 9.5 minutes to assess a textbook using the ELT-TEC. This was considerably shorter (almost three times) as compared with the time spent using the Skierso (1991) Checklist (28.5 minutes). The checklist has been tested for its concurrent validity of its results with those of other well established instruments (Skierso, 1991) and strong correlations $(\mathrm{r}=0.75)$ have been achieved (Mukundan\& Nimehchisalem, 2012).

\subsubsection{The Reliability of the Instrument}

The checklist has been tested for its reliability (Mukundan \& Nimchisalem, 2012). Inter-rater reliability tests have shown acceptable reliability coefficients $(\mathrm{r}=.962)$. For the present study, the internal reliability was calculated.

\begin{tabular}{|c|c|}
\hline $\begin{array}{l}\text { Cronbach's } \\
\text { Alpha }\end{array}$ & $\mathrm{N}$ of Items \\
\hline .962 & 3 \\
\hline
\end{tabular}

Table 2 presents the Cronbach reliability statistics for ELT-TEC. The relaibailty is considerably high $(\mathrm{r}=.962)$. 


\section{Results \& Discussions}

This section discusses the results of the study. The results have been presented following the order of the research questions.

\subsection{General attributes in Yearl-Year6 \& Form1-Form 5 textbooks}

The first research question was "how did the teachers evaluate the general attributes of the textbooks?" Table 3 shows the results for general attributes in Year 1 to Year 6 textbooks.

Table 3.General attributes in Year 1-Year 6 textbooks

\begin{tabular}{lcc}
\hline Grade & Mean & SD \\
\hline Year 1 & 2.92 & 0.53 \\
Year 2 & 2.87 & 0.62 \\
Year 3 & 2.92 & 0.53 \\
Year 4 & 2.94 & 0.48 \\
Year 5 & 2.96 & 0.55 \\
Year 6 & 2.88 & 0.60 \\
\hline
\end{tabular}

Key: 0-0.8 = Negligible usefulness, $0.81-1.6=$ Low usefulness, $1.61-2.80=$ Moderate usefulness, $2.81-3.6=$ High usefulness, 3.61-4 = Very high usefulness

According to the table, the mean scores for Year 1- Year 6 showed that all the teachers agreed that the current books that are being used in the schools are highly useful. The highest mean score $(\mathrm{M}=2.96, \mathrm{SD}=0.55)$ was reported for Year 5 textbook, whereas the lowest mean score $(\mathrm{M}=2.87, \mathrm{SD}=0.62)$ was reported for Year 2 textbook. Evidently, there is not a considerable difference among the mean scores of the five textbooks. The findings of this part are in congruence with Aroo (2012) and Ping (2011) that used the older version of the ELT-TEC to evaluate Year 2 and Year 1 textbooks. They found that Year 2 and Year 1 teachers had agreed on high usefulness of the textbooks.

Table 4 shows how the teachers evaluated Form 1 to Form 5 textbooks regarding their general attributes. Based on the teachers' evaluation, the currents books are moderately useful for the secondary students.

\begin{tabular}{lcc}
\multicolumn{3}{l}{ Table 4.General attributes in Form 1-Form 5 textbooks } \\
\hline Grade & Mean & SD \\
\hline Form 1 & 2.52 & 0.59 \\
Form 2 & 2.54 & 0.59 \\
Form 3 & 2.47 & 0.58 \\
Form 4 & 2.29 & 0.61 \\
Form 5 & 2.34 & 0.55 \\
\hline
\end{tabular}

The highest mean score $(\mathrm{M}=2.54, \mathrm{SD}=0.59)$ was reported for Form 2 textbook, whereas the lowest mean score $(\mathrm{M}=2.29, \mathrm{SD}=0.61)$ was reported Form 4 textbook. The findings of secondary level (Form 1-Form 5) were unlike the primary (Year 1-Year 6) level.

4.2 Learning-teaching content in Year1-Year6 \& Form 1-Form 5 textbooks

The second research question was "how did the teachers evaluate the learning-teaching content of the textbooks?" Table 5 shows the results for learning-teaching content in Year 1 to Year 6 textbooks.

Table 5. Learning-teaching content Year 1-Year 6 textbooks

\begin{tabular}{lcc}
\hline Grade & Mean & SD \\
\hline Year 1 & 2.95 & 0.50 \\
Year 2 & 2.94 & 0.66 \\
Year 3 & 2.86 & 0.53 \\
Year 4 & 2.86 & 0.51 \\
Year 5 & 2.87 & 0.61 \\
Year 6 & 2.84 & 0.65 \\
\hline
\end{tabular}

Based on the teachers' evaluations, the current Year 1- Year 6 books are highly useful. The highest mean score $(\mathrm{M}=2.95, \mathrm{SD}=0.50)$ was obtained for Year 1 textbook, whereas the lowest mean score $(\mathrm{M}=2.84, \mathrm{SD}=0.65)$ was reported for Year 6 textbook. Overall, there was not a remarkable difference among the mean scores assigned for the five textbooks. These findings are consistent with Aroo (2012) and Ping's (2011). Their evaluation of Year 2 and Year 1 textbooks indicated high usefulness of both textbooks.

Table 6 shows the results for learning-teaching content in Form 1 to Form 5. As can be seen, teachers in these grades reported that the current books are moderately useful for secondary students. 


\begin{tabular}{lcc}
\multicolumn{3}{l}{ Table 6. Learning-teaching content in Form 1-Form 5 textbooks } \\
\hline Grade & Mean & SD \\
\hline Form 1 & 2.59 & 0.60 \\
Form 2 & 2.61 & 0.60 \\
Form 3 & 2.61 & 0.49 \\
Form 4 & 2.38 & 0.64 \\
Form 5 & 2.32 & 0.61 \\
\hline
\end{tabular}

The highest mean scores $(\mathrm{M}=2.61, \mathrm{SD}=0.60 \& \mathrm{M}=2.61, \mathrm{SD}=0.49)$ were reported for Form 2 and Form 3 textbooks, respectively. In contrast, the lowest mean score $(\mathrm{M}=2.32, \mathrm{SD}=0.61)$ was reported for Form 5 textbook. The findings show that primary level (Year 1-Year 6) textbooks are of higher usefulness compared with secondary level (Form 1Form 5) textbooks.

\section{Conclusion \& Implication}

Textbook evaluation is considered very substantial because the information, which is collected, can be used for making decisions about the future of the textbooks (Sultana, Khan, Ali, \& Rehman, 2007). In order to adjust and improve a curriculum, textbooks and the materials used in the ELT program need to be improved. This is not possible unless teachers who are involved directly in the ELT program evaluate them on the basis of some established criteria provided by checklists.

In terms of general attributes and learning-teaching content of the textbooks, the teachers reported that the current Year 1 to Year 6 textbooks are highly beneficial to the students, whereas Form 1 to Form 5 teachers contended that the school books are moderately useful.

Generally, although there were two contradictory views on the usefulness of the Malaysian school English textbooks reported by primary and secondary school teachers, the findings of this study can be used as a reference for improving or modifying the textbooks. In addition the Ministry of Education can use these findings to seek strengths and weaknesses of the textbooks and update school English learning-teaching materials along with considering their suitability to the learners. Further studies can be carried out by observing the way in which the textbooks are used in the language classrooms.

This study emphasizes the role of retrospective evaluation of textbooks. It is very important to evaluate the usefulness of any textbook while it is being used. The results of such an evaluation can shed light on the probable weaknesses of the textbook that can lead to important adaptations.

\section{References}

Aroo, G. (2012). An evaluation of year two English textbook in primary school. (Unpublished thesis) .University Putra Malaysia, Serdang, Malaysia.

Banegas, D.L. (2011). Teaching More Than English in Secondary Education. ELT Journal, 65(1), 80-82.

Byrd, P. (2001). Textbooks: Evaluation for Selection and Analysis for Implementation. In M. Celce-Murcia (Eds.), Teaching English as a Second or Foreign Language (3rd ed.,pp.415-427). US: Heinle\&Heinle.

Chao, T. C. A. (2010). Retrospective Evaluation of a Local College English Textbook From an Intercultural Perspective. Studies in English for Professional Communications and Applications, 89.

Cunningsworth, A. (1984). Evaluating and Selecting EFL Teaching Materials.London: Heinemann.

Dendrinos, B. (1992). The EFL Textbook and Ideology. Greece: N.C. Grivas Publications.

Ghazali, M. (2008). A Reflection of the Revised Syllabus Translated in Textbooks. Journal on International Management Studies, February, 162-169.

Genesee, F. (2001). Evaluation. In R. Carter, \& D. Nunan (Eds.), The Cambridge guide to teaching English to speakers of other languages(pp. 144-150). Cambridge: Cambridge University Press.

Harmer, J. (1991).The Practice of English Language Teaching. New York: Longman Publishing.

Haycroft, J. (1998). An introduction To English language teaching. London: Longman.

Hutchinson, T. (1987). 'What's Underneath?: An Interactive View of Materials Evaluation'. In L. Sheldon. (Ed). ELT Textbook and Materials: Problems in Evaluation and Development (pp.37-44).Oxford: Modern English Publications.

Hutchinson, T., \& Torres, E. (1994).The Textbook as Agent of Change.ELT Journal, 48(4).

Kırkgöz, Y. (2009). Evaluating the English textbooks for young learners of English at Turkish primary education. Procedia-Social and Behavioral Sciences, 1(1), 79-83.

Lee, W. (1997). 'The Role of Materials in Classroom Language Use'.In V. Berry., B. Adamson., \& W. Littlewood. (Eds), Applying Linguistics: Insights into Language in Education (pp.69-82). Hong Kong: The University of Hong Kong. 
Lee, W. (1997). 'The Role of Materials in Classroom Language Use'.In V. Berry., B. Adamson., \& W. Littlewood. (Eds), Applying Linguistics: Insights into Language in Education (pp.69-82). Hong Kong: The University of Hong Kong.

Litz, D.R. (2005). Textbook evaluation and ELT management: A South Korean case study. Asian EFL journal, 6(4).

Mares, C. (2003). 'Writing a Coursebook'.In B. Tomlinson (Ed), Developing Materials for Language Teaching (pp.130-140). London: Continuum.

Masuhara, H. \& Tomlinson, B. (2008).Materials for General English. In B. Tomlinson (Ed), English Teaching Materials: A Critical Review (pp. 17-37). London: Continuum.

McDonough, J \& Shaw, C. (1993).Materials and methods in ELT: a teacher's guide. Oxford: Blackwell Pub.

Mukundan, J. (2007). 'Evaluation of English Language Textbooks: Some Important Issues for Consideration'. Journal of NELTA, 12(1\&2), 80-4.

Mukundan, J. (2003). Readings on ELT Material. Kuala Lumpur: Universiti Putra Malaysia Press.

Mukundan, J. \&Ahour, T. (2010). A Review of Textbook Evaluation Checklists across Four Decades (1970-2008). In B. Tomlinson, \& H. Masuhara, (Eds.).Research for Materials Development in Language Learning. London, UK: Continuum International Publishing Group.

Mukundan, J., Hajimohammadi, R., \&Nimehchisalem, V. (2011).Developing an English language textbook evaluation checklist.Contemporary Issues in Education Research. 4(6), 21-27.

Mukundan, J., Leong, A., \&Nimehchisalem, V. (2012).Distribution of articles in Malaysian secondary school English language textbooks, English Language and Literature Studies, 2(2), 62-70.Mukundan, J. \&Nimehchisalem, V. (2012).Evaluating the validity and economy of the English language teaching textbook evaluation checklist.World Applied Sciences Journal 20(3), 458-463. doi: 10.5829/idosi.wasj.2012.20.03.192

Mukundan, J., \&Nimehchisalem, V., Hajimohammadi, R. (2011). Developing an English Language Textbook Evaluation Checklist: A Focus Group Study. International Journal of Humanities Developing an English Language, l(12),100-105.

Mukundan, J., and Roslim, N. (2009).Recycling of prepositions in the Malaysian Secondary English Language Textbooks (Form 1-5).

Nemati, A. (2009). Evaluation of an ESL English coursebook: A step towards systematic vocabulary evaluation. Journal of Social Sciences, 20(2), 91-99.

Nimehchisalem, V. \&Mukundan, J. (In Press, a). Refinement of the English Language Teaching Textbook Evaluation Checklist.Pertanika Journal of Social Sciences and Humanities (JSSH).

Nimehchisalem, V. \&Mukundan, J. (In Press, b).Usefulness of the English Language Teaching Textbook Evaluation Checklist.PertanikaJournal of Social Sciences and Humanities (JSSH).

O’Neill, R. (1982). Why use textbooks? ELT Journal, 36(2), 104-111.

Pillay, H.D. (1995). Fragments of a Vision: A Case Study of the Implementation of an English Language Curriculum Programme in Five Malaysian Secondary Schools. Unpublished Ph.D. thesis.University of East Anglia.

Ping, H.Y. (2011). The evaluation of the primary year one English language textbook.(Unpublished thesis).University Putra Malaysia, Serdang, Malaysia.

Riazi, A. M., \&Mosalanejad, N. (2010).Evaluation of learning objectives in Iranian high-school and pre-university English textbooks using Bloom's taxonomy. TESL-EJ: The Electronic Journal for English as a Second Language, 13(4).

Sheldon, L. (1988). Evaluating ELT textbooks and materials. ELT Journal, 42(2), 237-246.

Sheldon, L. (1987). ELT Textbook and Materials: Problems in Evaluation and Development. Oxford: Modern English Publications.

Skierso, A. (1991). Textbook selection and evaluation. Teaching English as a second or foreign language, 432-453.

Sultana, R., Khan, R., Ali, U., \& Rehman, A. (2007). Evaluation of textbooks of English for secondary school students. Gomal University Journal of Reasearch.

Tomlinson, B. (2010). 'Principles of Effective Materials Development'.In N, Harwood (Ed.) (2010).English Language Teaching Materials: Theory and Practice. New York: Cambridge University Press.

Tomlinson, B. (Ed.) (2008). English Language Learning Materials: A Critical Review. London: Continuum.

Tomlinson, B. (2001). Materials development. In R. Carter, \& D. Nunan (Eds.), The Cambridge guide to teaching English to speakers of other languages (pp. 66-71). Cambridge, UK: Cambridge University Press.

Ur, P. (1996). A Course in Language Teaching: Practice and theory. UK: Cambridge University Press.

Williams, D. (1983). Developing Criteria for Textbook Evaluation. ELT Journal, 37(3), 251-255. 
Appendix 1

\section{ENGLISH LANGUAGE TEACHING TEXTBOOK EVALUATION CHECKLIST}

\section{$\underline{\text { INSTRUCTIONS }}$}

Read the items in the checklist and in the column opposite the items indicate the level to which they agree with each statement by marking 0 to 4 :

$0=$ NEVER TRUE

$1=$ RARELY TRUE

2 = SOMETIMES TRUE
$3=$ OFTEN TRUE

$4=$ ALWAYS TRUE

NA $=$ NOT APPLICABLE

NB: There may be one or more sections that you may not find applicable to your teaching context. In such cases, check the box in the 'NA' (or, NOT APPLICABLE) column and disregard the section in evaluating the textbook.

\begin{tabular}{|c|c|c|c|c|c|c|}
\hline $\begin{array}{c}\text { NA } \\
\square\end{array}$ & $\begin{array}{l}\text { I. General attributes } \\
\text { A. The book in relation to syllabus and curriculum } \\
\text { 1. It matches the specifications of the syllabus. } \\
\text { 2. Overall, the book has a nice feel. }\end{array}$ & $\begin{array}{l}\text { (1) } \\
\text { (1) }\end{array}$ & $\begin{array}{l}\text { (1) } \\
\text { (1) }\end{array}$ & $\begin{array}{l}\text { (2) } \\
\text { (2) }\end{array}$ & $\begin{array}{l}\text { (3) } \\
\text { (3) }\end{array}$ & $\begin{array}{l}\text { (4) } \\
\text { (4) }\end{array}$ \\
\hline $\begin{array}{c}\text { NA } \\
\square\end{array}$ & $\begin{array}{l}\text { B. Methodology } \\
\text { 3. The activities can be exploited fully. } \\
\text { 4. Activities can work well in most classroom situations. }\end{array}$ & $\begin{array}{l}\text { (1) } \\
\text { (1) }\end{array}$ & $\begin{array}{l}\text { (1) } \\
\text { (1) }\end{array}$ & $\begin{array}{l}\text { (2) } \\
\text { (2) }\end{array}$ & $\begin{array}{l}\text { (3) } \\
\text { (3) }\end{array}$ & $\begin{array}{l}\text { (4) } \\
\text { (4) }\end{array}$ \\
\hline $\begin{array}{c}\mathbf{N A} \\
\square\end{array}$ & $\begin{array}{l}\text { C. Suitability to learners } \\
5 . \quad \text { It is compatible with the background knowledge and level of students. } \\
6 . \text { It addresses learning targets. }\end{array}$ & $\begin{array}{l}\text { (1) } \\
\text { (1) }\end{array}$ & $\begin{array}{l}\text { (1) } \\
\text { (1) }\end{array}$ & $\begin{array}{l}\text { (2) } \\
\text { (2) }\end{array}$ & $\begin{array}{l}\text { (3) } \\
\text { (3) }\end{array}$ & $\begin{array}{l}\text { (4) } \\
\text { (4) }\end{array}$ \\
\hline $\begin{array}{c}\text { NA } \\
\square\end{array}$ & $\begin{array}{l}\text { D. Physical and utilitarian attributes } \\
\text { 7. It is appropriately priced. } \\
8 . \quad \text { Its layout is attractive. } \\
\text { 9. It indicates efficient use of text and visuals. }\end{array}$ & (1) & (1) & (2) & (3) & (4) \\
\hline $\begin{array}{c}\text { NA } \\
\square\end{array}$ & $\begin{array}{l}\text { E. Efficient layout of supplementary materials } \\
\text { 10. The book is supported by suitable materials, like a workbook, audio, } \\
\text { or multimedia. } \\
\text { 11. The book is supported by other materials like review and test units. } \\
\text { 12. There is a useful teacher's guide to aid the teacher. }\end{array}$ & $\begin{array}{l}\text { (1) } \\
\text { (1) }\end{array}$ & $\begin{array}{l}\text { (1) } \\
\text { (1) }\end{array}$ & (2) & $\begin{array}{l}\text { (3) } \\
\text { (3) }\end{array}$ & (4) \\
\hline $\begin{array}{c}\text { NA } \\
\square\end{array}$ & $\begin{array}{l}\text { II. Learning-teaching content } \\
\text { F. General content } \\
\text { 13. Tasks move from simple to complex. } \\
\text { 14. Tasks are varied. } \\
\text { 15. Tasks support teaching objectives. } \\
\text { 16. The language in the textbook is natural and real. } \\
\text { 17. The material is fairly recent. }\end{array}$ & $\begin{array}{l}\text { (1) } \\
\text { (1) } \\
\text { (1) } \\
\text { (1) } \\
\text { (0) }\end{array}$ & $\begin{array}{l}\text { (1) } \\
\text { (1) } \\
\text { (1) } \\
\text { (1) } \\
\text { (1) }\end{array}$ & $\begin{array}{l}\text { (2) } \\
\text { (2) } \\
\text { (2) } \\
\text { (2) } \\
\text { (2) }\end{array}$ & $\begin{array}{l}\text { (3) } \\
\text { (3) } \\
\text { (3) } \\
\text { (3) } \\
\text { (3) }\end{array}$ & $\begin{array}{l}(4) \\
(4) \\
(4) \\
(4) \\
(4)\end{array}$ \\
\hline $\begin{array}{c}\text { NA } \\
\square\end{array}$ & $\begin{array}{l}\text { G. Listening } \\
\text { 18. The book has appropriate listening tasks with well-defined goals. } \\
\text { 19. Tasks are authentic or close to real language situations. } \\
\text { 20. Various listening contexts such as formal vs. informal contexts are } \\
\text { considered. }\end{array}$ & $\begin{array}{l}\text { (0) } \\
\text { (0) } \\
\text { (0) }\end{array}$ & $\begin{array}{l}\text { (1) } \\
\text { (1) } \\
\text { (1) }\end{array}$ & $\begin{array}{l}\text { (2) } \\
\text { (2) } \\
\text { (2) }\end{array}$ & $\begin{array}{l}\text { (3) } \\
\text { (3) } \\
\text { (3) }\end{array}$ & $\begin{array}{l}(4) \\
(4) \\
(4)\end{array}$ \\
\hline $\begin{array}{c}\text { NA } \\
\square\end{array}$ & $\begin{array}{l}\text { H. Speaking } \\
\text { 21. Activities are developed to initiate meaningful communication. } \\
\text { 22. Individual, pair and group work are given equal emphasis. }\end{array}$ & $\begin{array}{l}\text { (1) } \\
\text { (1) }\end{array}$ & $\begin{array}{l}\text { (1) } \\
\text { (1) }\end{array}$ & (2) & $\begin{array}{l}\text { (3) } \\
\text { (3) }\end{array}$ & $\begin{array}{l}\text { (4) } \\
\text { (4) }\end{array}$ \\
\hline $\begin{array}{c}\text { NA } \\
\square\end{array}$ & $\begin{array}{l}\text { I. Reading } \\
\text { 23. Length is appropriate. } \\
\text { 24. Difficulty level is appropriate. } \\
\text { 25. Texts are interesting. }\end{array}$ & $\begin{array}{l}\text { (0) } \\
\text { (0) } \\
\text { (0) }\end{array}$ & $\begin{array}{l}\text { (1) } \\
\text { (1) } \\
\text { (1) }\end{array}$ & $\begin{array}{l}\text { (2) } \\
\text { (2) } \\
\text { (2) }\end{array}$ & $\begin{array}{l}\text { (3) } \\
\text { (3) } \\
\text { (3) }\end{array}$ & $\begin{array}{l}(4) \\
(4) \\
(4)\end{array}$ \\
\hline
\end{tabular}




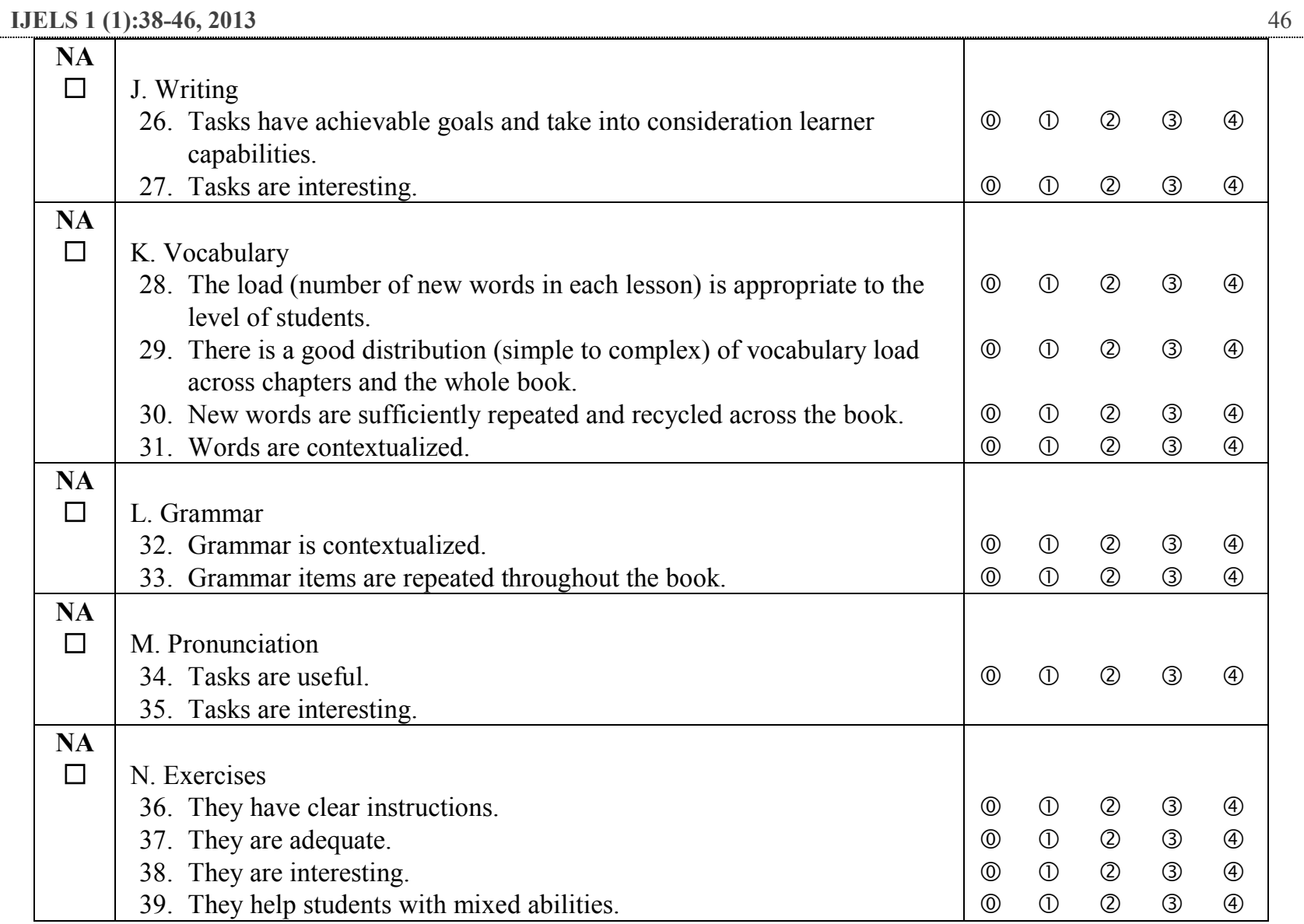

Table: Scores Interpretation Guide

\begin{tabular}{lll}
\hline Level & Range & Interpretation \\
\hline 0 & $0.00-0.80$ & Negligible usefulness \\
1 & $0.81-1.60$ & Low usefulness \\
2 & $1.61-2.80$ & Moderate usefulness \\
3 & $2.81-3.60$ & High usefulness \\
4 & $3.61-4.00$ & Very high usefulness \\
\hline
\end{tabular}

